\title{
Recent Decrease of Regional Disparity within Thailand
}

\author{
Kenji Nozaki \\ Correspondence: Kenji Nozaki, Faculty of Economics, Takasaki City University of Economics, Gunma, Japan. \\ Received: February 11, 2018 \\ doi:10.11114/bms.v4i2.3020 \\ Accepted: March 12, $2018 \quad$ Online Published: March 19, 2018 \\ URL: https://doi.org/10.11114/bms.v4i2.3020
}

\begin{abstract}
The existence of wage gaps between Thailand and its neighboring countries facilitate the division of labor in manufacturing production in the GMS. However, if the wage gap inside Thailand is too large, such effect is diminished. Under such recognition, this paper aims to clarify the recent situation of the regional disparity in Thailand.

The author acquired three findings. Firstly, the regional GINI coefficient in Thailand is confirmed to match Kuznets' inverted U-shaped curve. The analysis shows that the peak of the disparity occurred with income level in the early to mid-1990s. Secondly, the recent decrease of the disparity is partly explained by the changes in industrial policies. Export promotion policies introduced after import substitution in mid-1980s relocated the manufacturing production bases. It was followed by other supporting industries. They increased the income level of remote areas, and it caused the decrease of the regional disparity. Finally, the author found that the case of Thailand is different from the case of Indonesia. Even though Indonesia is also growing with foreign direct investment like Thailand, no Kuznets' U-shaped curve of regional disparity was observed.
\end{abstract}

Keywords: regional disparity, Kuznets' curve, trade liberalization, industrial dispersion

\section{Introduction}

This paper analyzes regional disparities within Thailand. Thailand is the most developed country in the Greater Mekong Sub-region (GMS), which has been strengthening its economic linkages in recent years. Thailand began industrialization earlier than neighboring countries. In the 1960s, it introduced an import substitution policy and increased its manufacturing production. Since the 1980s, it has promoted exports, accepting foreign direct investment. Thailand has achieved higher economic growth as a result. According to the IMF economic outlook database, per capita GDP of Thailand in 2016 is estimated as 5,902 US dollar, whereas other GMS members were lower, for example, 1,232 US dollar for Myanmar (Table 1).

Table 1. Per capita GDP of GMS countries in 2016

\begin{tabular}{llll}
\hline Country & per capita GDP (USD) & GDP (bil. USD) & Population (mil.) \\
\hline Cambodia & 1,278 & 20.2 & 15.8 \\
Lao P.D.R. & 2,394 & 15.8 & 6.6 \\
Myanmar & 1,232 & 64.4 & 52.3 \\
Thailand & 5,902 & 407.1 & 69.0 \\
Vietnam & 2,172 & 201.3 & 92.7 \\
\hline
\end{tabular}

(Source) IMF, World Economic Outlook Database (October 2017)

(Note) Figures of GDP per capita and population of Cambodia, Myanmar, Thailand and Vietnam are estimation by the IMF.

The gap of per capita GDP between Thailand and its neighbors can be interpreted as wage gap. It can facilitate the division of labor in production. As the cost of labor intensive process in Thailand increased, such process has been shifted to neighboring countries whose wages are cheaper. Such situation was discussed by Nozaki (2016), which discussed the division of labor in production in the GMS by using the fragmentation theory of Jones and Kierzkowski (1990). However, the division of labor in production will not hold if there is a large regional disparity within Thailand, because the wage gap between the border area in Thailand and the neighboring country will be small. The progress of division of labor in production in the GMS makes us expect that the regional disparity in Thailand is decreasing.

In order to improve the regional disparities, there are many policies which directly or indirectly influence the disparities. As for the direct policies, the government of Thailand noticed the need to broaden the income distribution and promote 
rural development since 1980s. It is normal for the governments of developing countries to pursue continuing economic growth at first. Negative side effects of rapid economic growth became apparent gradually, and the government should try to mitigate them. In the $11^{\text {th }}$ national economic and social 5 year plan, the government summarized its past development stance, as follows ${ }^{1}$. The Thai economy pursued economic growth during the $1^{\text {st }}$ to $4^{\text {th }}$ plans (1961-1981), according to a government led strategy. A new concept was introduced during the period of the $5^{\text {th }}$ to $8^{\text {th }}$ plans (1982-2001). The government focused on the need for rural development and poverty alleviation. Development of the Eastern Seaboard of Thailand, which promoted exports from Thailand, was conducted for this reason. In the meantime, indirect effects of policies should not be ignored. For example, changes in trade policies did not focus on the improvement of regional disparity. However, as Krugman and Elizondo (1996) pointed, they can influence the location of production, which has effects on regional income. Thus, there may be many reasons acting together to decrease the regional disparity.

Under the recognition mentioned above, this paper aims to shed light on three points. First, the trend and current regional disparity in Thailand are clarified. In particular, whether the regional disparity indicator conforms to Kuznets' inverted U-shaped curve is answered. Second, the relation is discussed between the trade policies of Thailand and regional disparities. As trade policies were liberalized in mid-1980s, manufacturing industry was dispersed, reducing regional disparity. This effect is studied. Third, the trend in Thailand is compared to the case of Indonesia, which is also an industrializing country with foreign direct investments.

\section{Literature Survey and Method of Analysis}

To quantify the disparity, Gini (1921) is well known and the GINI coefficient was introduced. It is expressed as

$$
G I N I=\frac{1}{2 \mu n^{2}} \sum_{j, i=1}^{n}\left|x_{i}-x_{j}\right|
$$

where $\mu$ is average income, $n$ is the number of samples, and $x_{i, j}$ denotes the income of each member (for example, household). This indicator runs from 0 to 1 ; if every member has identical income it is 0 , whereas if one member has all the income it takes value 1 . At the same time, the GINI coefficient can be derived from the Lorentz curve. This can be drawn by placing people from low to high income in order along the horizontal axis, and cumulative income along the vertical axis. Then the GINI coefficient is the ratio of arcuate area enclosed by the 45 -degree line and Lorentz curve to the area of the triangle formed by the 45-degree line and the vertical and horizontal axes. Bellow, supposing that the income is distributed equally in one region, the Lorenz curve is approximated and the Gini coefficient is calculated from the area ratio.

There are some other methods to express the level of disparity. They include Theil index, and mean log deviation. The Herfindahl index, which is generally used as an indicator of the degree of monopoly or oligopoly can be an alternative when we focus on the concentration of wealth. In an empirical analysis of Chinese disparity, for example, Wu (2007) used the Theil index, while Zhang (2008) calculated the GINI coefficient. In this paper, the author calculated the GINI coefficient from the Gross Regional Product (GRP) per capita weighted by regional population, following the study by Nozaki (2007) of regional disparity in Thailand.

In order to discuss the shift in disparity with economic development, Kuznets (1955) constructed a hypothesis of Kuznets' inverted U-shaped curve. In the initial stages of economic development, the disparity is small. It then increases with economic growth. When growth continues, the disparity reaches a maximum and then decreases gradually. When income level is plotted along the horizontal axis and the level of disparity along the vertical axis, the result is an inverted U-shaped curve. Although Kuznets' hypothesis was derived from empirical analysis, Kuznets himself expected further empirical analyzes to verify the hypothesis. Many studies were then conducted. Among them, Deininger and Squire (1998) is a comprehensive analysis. It concluded that the Kuznets' curves are observed about minor portion of countries if the country specific factors are eliminated. Even though, the application of the Kuznets' hypothesis is still controversial. In recent years, mitigation of disparity has been discussed as a policy issue, since many countries including Japan observe the increase in disparity. A recent Japanese government official report, the Cabinet Office (2007), analyzed the income disparity under the concept of Kuznets' hypothesis. In the case of Thailand, Ikemoto and Uehara (2000) studied whether the income disparity accompanying the progress of industrialization conforms to Kuznets' hypothesis of an inverted U-shaped curve. In recent years, Rueanthip (2012) considered the income disparity between urban and rural areas. This work estimated an inverted U-shaped curve for income disparity.

\footnotetext{
${ }^{1}$ National Economic and Social Development Board (NESDB) (2011), pp.131-133.
} 
These studies are for relationship between growth and income distribution in country level. As for the regional disparity, there are few studies to verify the Kuznets' hypothesis. For Thailand, researchers have discussed regional disparities. Ikemoto and Limskul (1987) studied income inequality and regional disparity in Thailand. Further work discussed regional disparity in Thailand, although the Kuznets' inverted U-shaped curve was not considered. For example, Yazawa (1992) found the trend of regional disparity in the increasing phase. However, regarding on the Kuznets' curve, it could not say that it traces on the inverted U-shaped curve, because it has not hit the maximum point of the inverted U-shaped curve. Ikemoto (2000) proposed the inverted U-shape, but Ishii (2002) asserted that it is too early to infer the decreasing phase, even though regional disparity began to decrease after the 1990s.

Kuznets' inverted U-shaped curve is also supposedly applicable to environmental problems. In the initial stage of economic development, emission of pollutants is small, but as economic development progresses through industrialization, emissions increase. As environmental measures then cut in, in parallel with further economic development, emissions turn to decrease. In environmental economics, many inverted U-shaped curves appear. It is useful to review these studies because they estimate function curves. Most of them estimate quadratic or cubic curves. For example, Selden and Song (1994), Holtz-Eakin and Selden (1995), and Hayami (1995) estimated quadratic curve, while Gossman and Kruger (1995) estimated cubic curve. Suri and Chapman (1998), which quoted the idea of Grossman and Kruger (1995), also estimated the quadratic curve. As de Bruyn, et al. (1998) mentioned, the functional form depends on the shape of the curve. If it is estimated as inverted U-shaped curve, the function form should be quadratic. On the contrary, if the estimation is $\mathrm{N}$-shaped curve, the function form should be cubic. As the $\mathrm{N}$-shape will appear in developed countries, estimation of developing countries such as Thailand will be suitable for inverted U-shape.

In this paper, the inverted U-shaped curve is estimated as a quadratic curve. The GINI coefficient is calculated from the Gross Regional Product (GRP) per capita weighted by regional population, following the study by Nozaki (2007) of regional disparity in Thailand.

\section{Analysis of Regional Disparity in Thailand}

This section contains three sub-sections. In the first part, the regional GINI coefficients are calculated from 1981 to 2013. It is then verified that these figures are valid for the Kuznets' U-shaped curve. In the second sub-section, in order to verify the relation between industrial dispersion and the movement of regional disparity, Herfindahl indexes of manufacture, commerce and GRP are calculated. In the third part, the case of Indonesia is surveyed for comparison.

\subsection{Economic Development and Regional Disparity}

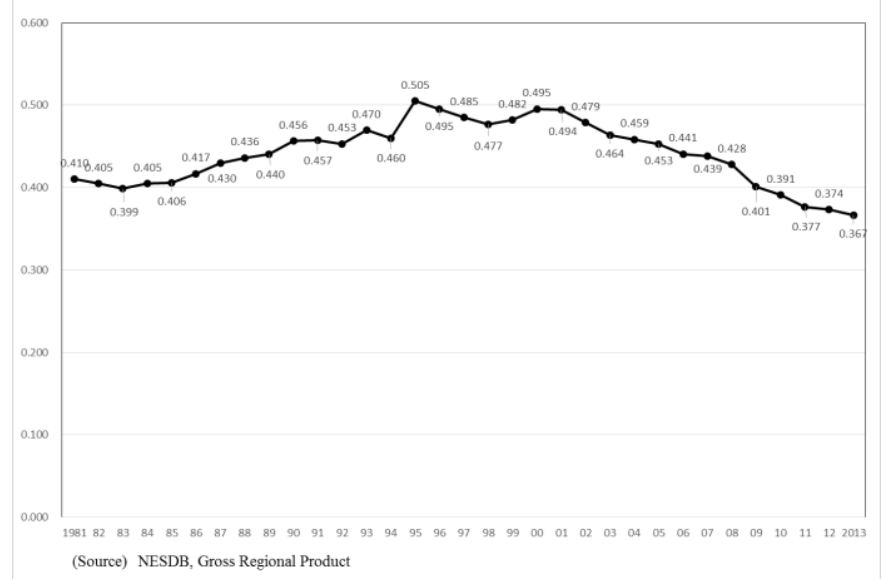

Figure 1. Regional GINI in Thailand

The regional GINI coefficients were calculated according to GRP. Data from 1981 to 1994 are series based on the 1988 standard, and data from 1995 to 2013 are to the current 2002 standard. For regions, the author followed the division of regions by NESDB category ${ }^{2}$. These comprise seven regions, namely Northeastern, Northern, Southern, Eastern, Western, Central and Greater Bangkok. Table 2 sets out the composition of each province.

Figure 1 sets out the results of calculations. Regional disparity clearly increased from the 1980s to the early 1990s, reaching a maximum in 1995 . The regional GINI coefficient reached 0.505 . The absolute value of the GINI coefficient

\footnotetext{
${ }^{2}$ The National Statistical Office of Thailand recognizes five regions. In this paper, division into seven regions is adopted, according to NESDB data.
} 
is not so significant ${ }^{3}$, but the concentration in Greater Bangkok was great in that period. The regional GINI coefficient then decreases. It was 0.367 in 2013, which was still large but much smaller than in the early 1990s. According to Nozaki (2007), the Asian financial crisis during 1997 to 2000 made analysis difficult because the regional GINI coefficient fluctuated. As a new data became available, the decreasing trend became clear, and the fluctuation during the Asian crisis was confirmed. This fluctuation occurred because the Asian crisis damaged the service sector more than the manufacturing sector, which implies that the high-income region was damaged more. Therefore, in the recovering stage in 1999, the regional GINI coefficient increased again. This will be discussed later in the context of average income change, because income itself decreased during the crisis, and the shift in disparity can be understood in terms of Kuznets' hypothesis.

Table 2. Provinces of each region in Thailand

\begin{tabular}{l|l}
\hline Northeastern region (20) & $\begin{array}{l}\text { Khonkaen, Udonthani, Loei, Nongkhai, Mukdahan, Nakhonphanom, Sakonnakhon, Kalasin, } \\
\text { Nakhonratchasima, Chaiyaphum, Yasothon, Ubonratchathani, Roiet, Buriram, Surin, } \\
\text { Mahasarakham, Sisaket, Nongbualamphu, Amnatchareon, Buengkan, }\end{array}$ \\
\hline Northern region (17) & $\begin{array}{l}\text { Chiangmai, Lampang, Uttaradit, Maehongson, Chiangrai, Phrae, Lamphun, Nan, Phayao, } \\
\text { Nakhonsawan, Phitsanulok, Kamphaengphet, Uthaithani, Sukhothai, Tak, Phicht, Petchabun, }\end{array}$ \\
\hline Southern region (14) & $\begin{array}{l}\text { Phuket, Suratthani, Ranong, Phangnga, Krabi, Chumphon, Nakhon si thammarat, Songkhla, } \\
\text { Satun, Yala, Trang, Narathiwat, Phatthalung, Pattani, }\end{array}$ \\
\hline Eastern region (8) & Chonburi, Chachoengsao, Rayong, Trat, Chanthaburi, Nakhonnayok, Prachinburi, Sakeaw, \\
\hline Western region (6) & Ratchaburi, Kanchanaburi, Phachuapkhirikhan, Petchaburi, Supanburi, Samutsongkhram, \\
\hline Central region (6) & Saraburi, Singburi, Chainat, Angtong, Lopburi, Phranakhonsriayuthaya, \\
\hline Greater Bangkok (6) & Bangkok metropolis, Samutprakan, Pathumthani, Samutsakhon, Nakhonpathom, Nonthaburi \\
\hline
\end{tabular}

(Source) NESDB 'Gross Regional and Provincial Product of Thailand'

(Note) Numbers in brackets are the number of the provinces in each region.

In recent years, significant change has taken place. According to the Lorentz curve (Figure 2), the eastern region has become the region of highest income. From the distant past to recent years, Greater Bangkok had maintained its position. The Lorentz curves for 1981 and 2013 look similar; only the eastern region and Greater Bangkok show any difference. This implies that the development of the eastern region contributed to the decrease in regional disparity in the long run. On the other hand, other regions including northeastern, northern and others, although diverging from Greater Bangkok in the 1980s and 1990s, are now catching up with advanced regions. They have contributed to the decreasing trend in recent years. The ratio of per capita GRP in Greater Bangkok to that in the eastern region was 2.4 times in 1981. This shrank to 1.7 in 1995, and as the eastern region became larger in 2012, the ratio in 2013 is 0.87.

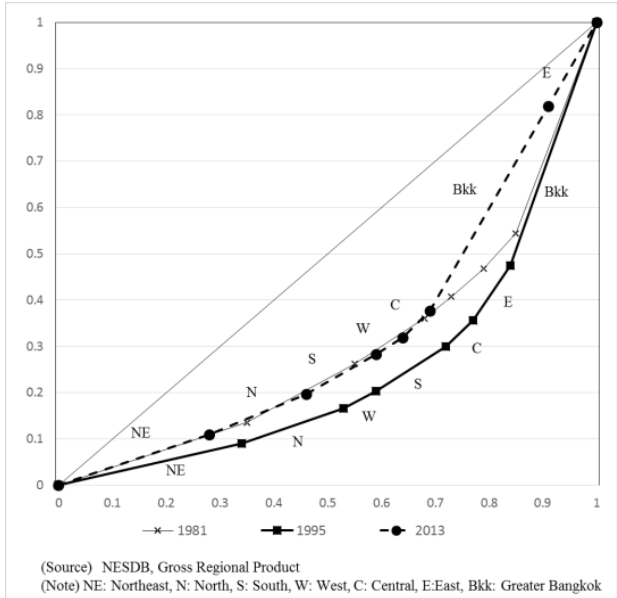

Figure 2. Lorentz curve for regional disparity in Thailand

\footnotetext{
${ }^{3}$ The GINI coefficient is calculated by GRP, so the figures should be overestimates. This is partly because GRP in Thailand is summed up from the supply side. A substantial portion of sales or shipments of a satellite office in a local region may therefore be counted as those of head offices in the metropolis. Another possibility is neglect of remittance from metropolis to local regions. As Nozaki (2007) pointed out, the regional GINI gap between GRP and household income can be explained in such ways.
} 
The Kuznets' inverted U-shaped curve is now constructed. The decrease in regional disparity from the mid-1990s suggests that an inverted U-shaped curve can be fitted. To confirm this, we need a significant relationship between the income and the indicators of disparity. Accordingly, the horizontal axis can plot the per capita GDP of Thailand on a nominal US dollar basis, and the vertical axis is for the GINI coefficient, so as to draw a scatter plot. Hayami (1995) and others estimated a quadratic curve, and the present analysis does the same. Because the income distribution follows a lognormal distribution, GINI coefficients are expressed on a \% basis. It is because if the value is less than 1, the logarithm is negative. The result of the estimation is summarized in Table 3, and the scatter plot is shown in Figure 3. The estimation of the quadratic curve gives:

$$
\ln (\mathrm{GINI})=-0.2019 *\left(\ln y_{n}\right)^{2}+3.0624 * \ln y_{n}-7.0652\left(\mathrm{R}^{2}=0.8488\right)
$$

where $\mathrm{y}_{n}$ is the per capita GDP of Thailand in nominal US dollars.

Table 3. Kuznets' inverted U-shaped curve for regional disparity

\begin{tabular}{l|lc|ll}
\hline Dependent Variables & Thailand & & \\
\hline per capita GDP $($ square $):\left(\ln \mathrm{y}_{\mathrm{n}}\right)^{2}$ & $-0.2019^{* * * *}$ & $(-13.43)$ & -0.0643 & $(-0.10)$ \\
\hline per capita GDP: $\ln \mathrm{y}_{\mathrm{n}}$ & $3.0624^{* * * *}$ & $(13.38)$ & 0.0040 & $(0.09)$ \\
\hline Const. & $-7.0652^{* * * *}$ & $(-8.14)$ & 3.3394 & $(1.48)$ \\
\hline Sample & 33 & & 34 & \\
\hline Adjusted R & & -0.0620 & \\
\hline S. E. of regression & 0.8488 & & 0.0759 & \\
\hline
\end{tabular}

(Source) IMF 'Economic outlook database', NESDB Thailand 'Gross Regional Product', BPS Indonesia 'Statistical yearbook of Indonesia'.

(Note) $* * *$ indicates significance at the 1 per cent level. The figures in parentheses denote t-statistics.

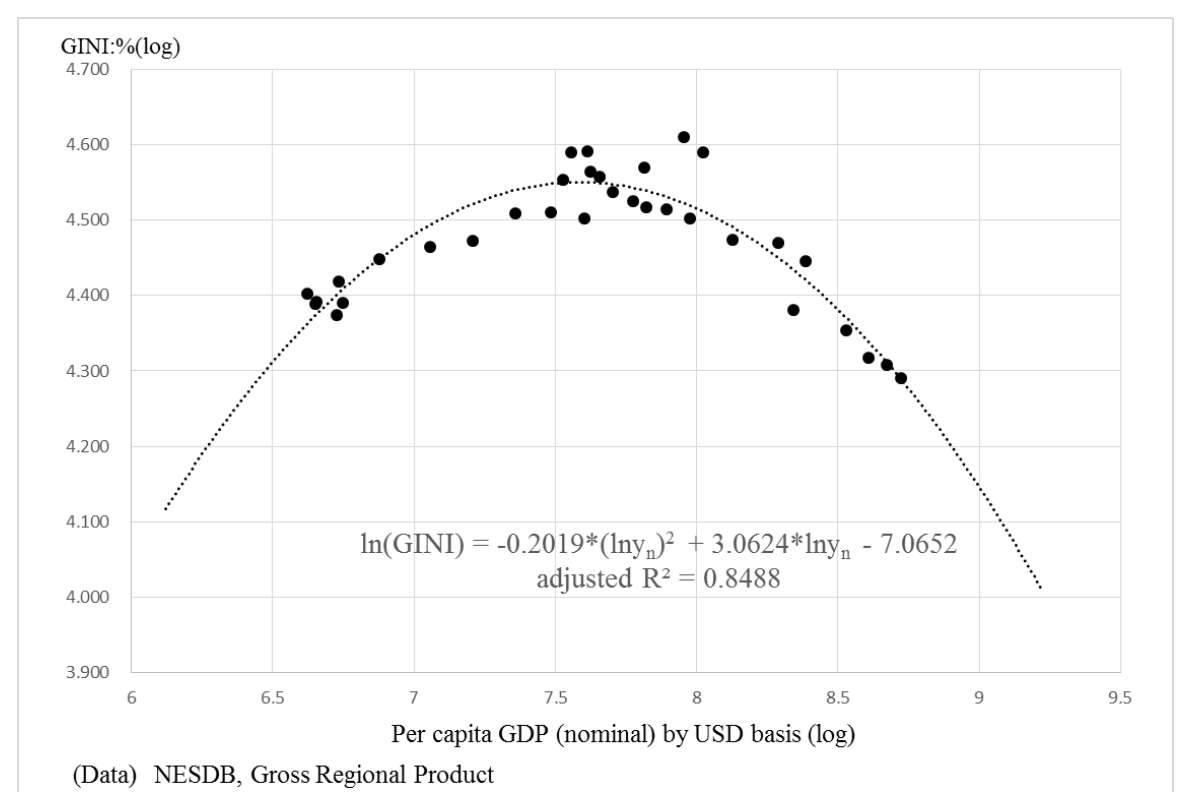

Figure 3. Inverted U-shaped curve for regional disparity in Thailand

Based on this estimation, we can confirm, in accordance with the trajectory of the quadratic curve, that regional disparity expanded with rising income, and after the income exceeding the maximum disparity, a contraction trend begins. When the regional disparity is maximum, the equation indicates that the per capita GDP is 1,966 US dollars. It was around 1992, when Thailand reached such income level. This result also explains the fluctuation in the regional GINI coefficient during the Asian financial crisis. The decrease of the regional GINI coefficient from 1996 to 1998 was due to decrease of per capita GDP, namely reverse movement along the Kuznets' inverted U-shaped curve. With recovering of the per capita GDP after several years, the GINI coefficient increased again, and once again exceeding of the critical point of per capita GDP, it started to tend to decrease.

\subsection{Liberalization of Trade Policies and Regional Disparity}

There may be many reasons acting together to decrease the regional disparity. This sub-section considers the relation between changes in regional disparity and industrial dispersion. As Nozaki (2014) pointed out, in reference to the 
Krugman and Elizondo (1996) model, manufacturing was shifted to local regions with changes in trade policies, from import substitution to liberalization in the 1980s. During the import substitution period, manufacturing was concentrated into Greater Bangkok. The Herfindahl index of manufacturing production based on seven regions peaked in the late 1980s and then decreased gradually (Figure 4). The point is that there is 5-10 years lag in the decrease in regional disparity after the peak of concentration of manufacturing in Greater Bangkok. This can be explained by other industries such as the service sector, which follows manufacturing. Since the wage level, which can be interpreted as the income level, should be higher than in other industries, the regional disparity continued to increase for some years while the service industry continued to concentrate. Figure 4 shows that the service industry continued to concentrate until around 2000, and then began to disperse. Summing up all industries together, the GRP concentration peaked around in the mid-1990s, which is consistent with the movement in regional disparity.

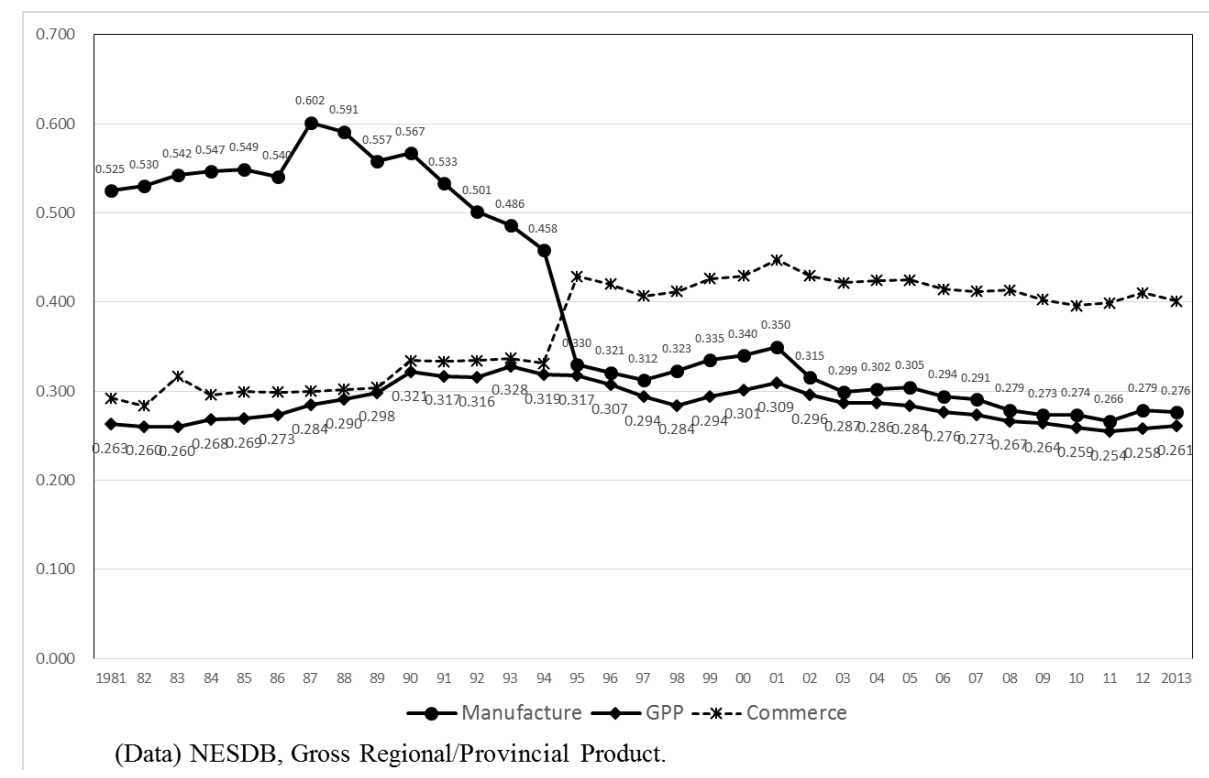

Figure 4. Herfindahl Index of GRP/Manufacturing/Commerce in Thailand

As industrial dispersion took place due to liberalization of trade policies according to Nozaki (2014), trade liberalization indirectly contributed to the mitigation of regional disparity.

\subsection{Comparison with Indonesia}

This sub-section analyzes the regional disparity in Indonesia. Indonesia also industrialized by accepting foreign direct investments from the 1980s. Per capita GDP in 2016 is estimated as high as 3,604 US dollars, which is less than per capita GDP in Thailand in the same year but more than that in the 1990s. If other conditions were the same as Thailand, the income level should be in the decreasing phase of regional disparity now. Some work supports the opposite idea, however. Based on the Krugman and Elizondo (1996) model, Sjöberg and Sjöholm (2004) conducted an empirical analysis on Indonesia. They found that industrial dispersion was not verified even after liberalization of trade policies. They suggested that this is due to the special conditions in Indonesia as an archipelago nation, within which shifts of production site are difficult.

Table 4. Provinces in each region in Indonesia

\begin{tabular}{l|l}
\hline Sumatera (10) & $\begin{array}{l}\text { Aceh, Sumatera Utara, Sumatera Barat, Riau, Jambi, Sumatera Selatan, } \\
\text { Bengkulu, Lampung, Kepulauan Bangka Belitung, Kepulauan Riau }\end{array}$ \\
\hline Jakarta (1) & DKI Jakarta \\
\hline Jawa and Bali (6) & Jawa Barat, Jawa Tengah, DI Yogyakarta, Jawa Timur, Banten, Bali \\
\hline Kalimantan (5) & $\begin{array}{l}\text { Kalimantan Barat, Kalimantan Tengah, Kalimantan Selatan, Kalimantan Timur, } \\
\text { Kalimantan Utara }\end{array}$ \\
\hline Sulawesi (6) & $\begin{array}{l}\text { Sulawesi Utara, Sulawesi Tengah, Sulawesi Selatan, Sulawesi Tenggara, } \\
\text { Gorontalo, Sulawesi Barat }\end{array}$ \\
\hline Others (6) & $\begin{array}{l}\text { Nusa Tenggara Barat, Nusa Tenggara Timur, Maluku, Maluku Utara, Papua Barat, } \\
\text { Papua }\end{array}$ \\
\hline
\end{tabular}

(Source) Statistical yearbook of Indonesia 
(Note) Numbers in brackets are the number of the provinces in each region.

Accordingly, the author calculated the regional GINI coefficient for Indonesia. The country was divided into six regions, Sumatera, Jakarta, Jawa and Bali (excluding Jakarta), Kalimantan, Sulawesi and others ${ }^{4}$. The composition of each province is described in Table 4. Using the same method of measuring the regional GINI coefficient of Thailand, the author calculated the regional GINI coefficient for Indonesia. The result is shown in Figure 5. Distinct from Thailand, no clear trend can be observed. The GINI coefficient is much smaller than for Thailand, although direct comparison is not appropriate because there are some differences in conditions.

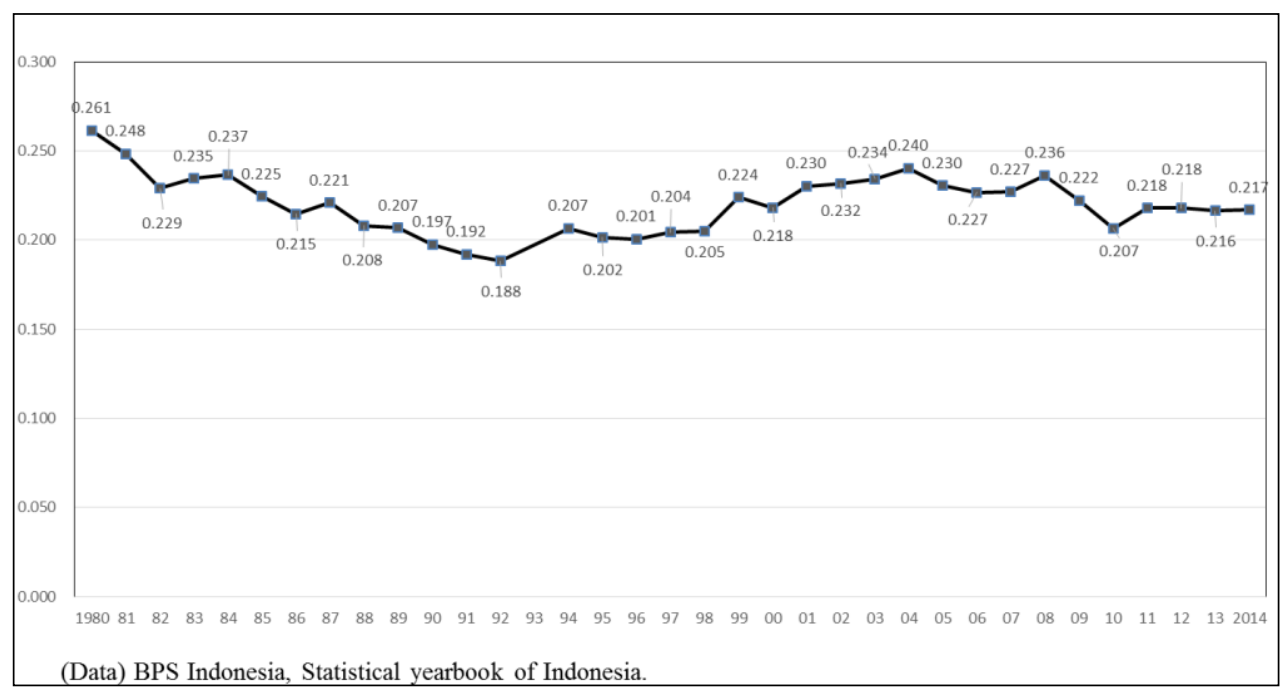

Figure 5. Regional GINI in Indonesia

The Kuznets' inverted U-shaped curve was then constructed. In the scatter plot of per capita GDP in US dollar basis (horizontal axis) and the regional GINI coefficient (vertical axis), no clear inverted U-shaped curve was visible. No clear relationship can be discerned (Figure 6). If the quadratic model is applied, the estimation gives:

$$
\ln (\mathrm{GINI})=0.004 *\left(\ln y_{n}\right)^{2}-0.0643 *\left(\ln y_{n}\right)+3.3394\left(\mathrm{R}^{2}=-0.0620\right)
$$

where $y_{n}$ is the per capita GDP of Indonesia in nominal US dollars. The estimation period runs from 1980 to 2014 (Table 3).

As implied by Sjöberg and Sjöholm (2004), regional disparity in Indonesia was apparently uninfluenced by changes in trade policies. The figures suggest that, even in the import substitution period, industry did not concentrate into Jakarta significantly.

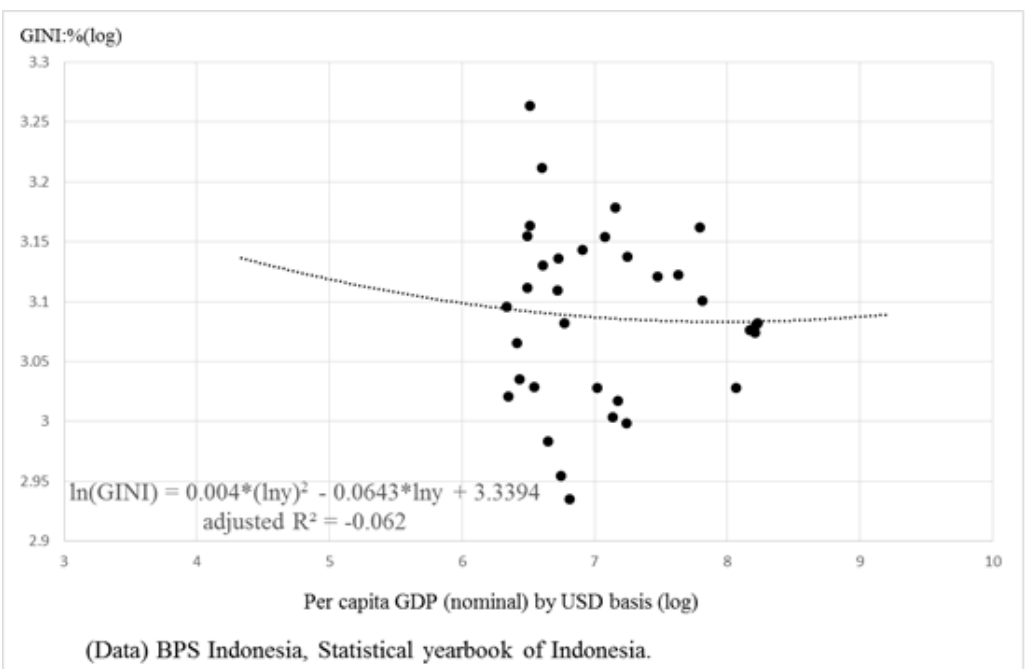

Figure 6. Regional disparity and per capita GDP in Indonesia

\footnotetext{
${ }^{4}$ Eastern Timor was excluded from analysis even before independence.
} 


\section{Conclusion and Future Work}

This paper has confirmed that regional disparity in Thailand has changed, by tracing the inverted U-shaped curve. It peaked out when the per capita GDP level was around 2,000 US dollars. Then trend of disparity is decreasing with increasing per capita GDP. The disparity widened during the 1980s due to concentration of the manufacturing sector under import substitution policies. When the government of Thailand changed its trade policy to become export oriented and moved toward trade liberalization, manufacturing followed by other service industries, dispersed into local areas, particularly the eastern region. This significantly reduced regional disparity. These are key findings of this paper.

In regard to economic linkage, especially the production network within the GMS, progress in equalizing regional income within Thailand will facilitate the division of labor in the production process. If there remains regional disparity in Thailand, which can be translated that relatively cheap labor still exists in local area of Thailand, such progress will be curved. Meanwhile, in order to give a precise consideration on economic linkage in the GMS, to study regional disparity in other GMS countries is significant. According to the comparison with the case of Indonesia, the author could not find a same trend as Thailand. To generalize the phenomenon is difficult as the reasons of changes in regional disparity are various. Therefore, we need surveys for each country. As it is very difficult to collect enough data for the time, it should be future subjects.

\section{References}

Cabinet Office. (2007). Annual Report on the Japanese Economy and Public Finance 2007.

de Bruyn, S. M., van den Bergh, J. C. J. M., \& Opschoor, J. B. (1998). Economic growth and emissions: Reconsidering the empirical basis of environmental Kuznets curves. Ecological Economics, 25(2), 161-175. https://doi.org/10.1016/S0921-8009(97)00178-X

Deininger, K., \& Squire, L. (1998). New ways of looking at old issues: Inequality and growth. Journal of Development Economics, 57(2), 257-285. https://doi.org/10.1016/S0304-3878(98)00099-6

GINI, C. (1921). Measurement of Inequality of Incomes. Economic Journal, 31(121), 124-126. https://doi.org/10.2307/2223319

Grossman, G. M., \& Kruger, A. B. (1995). Economic growth and the environment. Quarterly Journal of Economics, 110(2), 353-377. https://doi.org/10.2307/2118443

Hayami, Y. (1995). Development Economics, Sobunsha. (in Japanese)

Holtz, E. D., \& Selden, T. M. (1995). Stoking the fires? CO2 emissions and economic growth. Journal of Public Economics, 57(1), 85-101. https://doi.org/10.1016/0047-2727(94)01449-X

Ikemoto, Y. (2000). Diversity of regional disparities in Thailand. In K. Ohno (ed.), Economic development and structure of regional economies (Institute of Development Economies) (pp. 59-81). (in Japanese).

Ikemoto, Y., \& Limskul, K. (1987). Income inequality and regional disparity in Thailand, 1962-81. The Developing Economies, 25(3), 249-269. https://doi.org/10.1111/j.1746-1049.1987.tb00109.x

Ikemoto, Y., \& Uehara, M. (2000). Income inequality and Kuznets' hypothesis in Thailand. Asian Economic Journal, 14(4), 421-443. https://doi.org/10.1111/1467-8381.t01-1-00117

Ishii, Y. (2002). Consideration on movement of regional disparities in the developing countries. Rikkyo Economic Studies, 56(1), 255-281. (in Japanese)

Jones, R. W., \& Kierzkowski, H. (1990). The Role of Services in Production and International Trade: A Theoretical Framework, In: Jones R. and Kruger, A. (Eds.), The Political Economy of International Trade: Essays in Honor of Robert E. Baldwin (pp.31-48). Basil Blackwell, Oxford.

Krugman, P., \& Elizondo, R. L. (1996). Trade policy and the third world metropolis. Journal of Development Economics, 49(1), 137-150. https://doi.org/10.1016/0304-3878(95)00055-0

Kuznets, S. (1955). Economic growth and income inequality. American Economic Review, 45(1), 1-28.

NESDB. (2011). The eleventh national economic and social development plan.

Nozaki, K. (2007). Regional disparity in Thailand: Conditions in a society with demographic mobility. The Economic Science (Nagoya University), 55(3) 181-198 (in Japanese). http://doi.org/10.18999/ecos.55.3.181

Nozaki, K. (2014). Industrial dispersion in Thailand with changes in trade policies. International Journal of Asian Social Science, 4(7), 806-819.

Nozaki, K. (2016). Progress in Intra-industry Trade in the Greater Mekong Sub-region. Foreign Trade Review, 51(2), 
147-161. DOI: https://doi.org/10.1177/0015732515625708

Rueanthip, K. (2012). The Urban-Rural Income Inequality in Thailand: 1996-2011. The Economic Science (Nagoya University), 60(2), 25-43. DOI: http://doi.org/10.18999/ecos.60.2.25

Selden, T. M., \& Song, D. (1994). Environmental quality and development: Is there a Kuznets' curve for air pollution problems? Journal of Environmental Economics and Management, 27(2), 147-162. https://doi.org/10.1006/jeem.1994.1031

Sjöberg, O., \& Sjöholm, F. (2004). Trade liberalization and the geography of production: Agglomeration, concentration, and dispersal in Indonesia's manufacturing industry. Economic Geography, 80(3), $287-310$. https://doi.org/10.1111/j.1944-8287.2004.tb00236.x

Suri, V., \& Chapman, D. (1998). Economic growth, trade and energy: Implications for the environmental Kuznets curve. Ecological Economics, 25(2), 195-208. https://doi.org/10.1016/S0921-8009 (97)00180-8

Wu, H. (2007). The West Development Strategy and regional disparity in China. The Economic Science (Nagoya University), 55(3), 49-68 (in Japanese). DOI: http://doi.org/10.18999/ecos.55.3.49

Yazawa, H. (1992). Regional disparity in Thailand. Asian Economies (Institute of Development Economies), 33(6), 56-71 (in Japanese).

Zhang, J. (2008). The development of regional economy and regional disparity. Xue, J. et al (ed.) Inequality in China. 53-64 (in Japanese).

\section{Copyrights}

Copyright for this article is retained by the author(s), with first publication rights granted to the journal.

This is an open-access article distributed under the terms and conditions of the Creative Commons Attribution license which permits unrestricted use, distribution, and reproduction in any medium, provided the original work is properly cited. 